\title{
Cladistic Analysis of Species Infesting (Amblycera: Menoponidae) Fowls of District Hyderabad, Sindh, Pakistan
}

\author{
Farheen Shaikh*, Saima Naz and Nadir Ali Birmani
}

\author{
Department of Zoology, \\ University of Sindh, \\ JAMSHORO-76080 (SINDH) PAKISTAN \\ *Corresponding Author \\ Email : farhee78@yahoo.com
}

Received : 18.10.2019; Accepted : 14.11.2019

\begin{abstract}
The present research work covers the phylogentic relationship of five species belonging to a family Menoponidae (Amblycera: Phithraptera), recovered from variety of fowls as host from district Hyderabad, Sindh Pakistan. These were analyzed cladistically by cladogram, using of their apomorphic characters. The Key to the five species of family Menoponidae has also been developed for the three genera. This is the first attempt to cladistics analysis of the family Menoponidae from district Hyderabad, Sindh, Pakistan.

\section{Introduction}

Lice are highly successful ectoparasites. Most species of mammals and birds are infested by about at 1- 6 species of lice at one time which are causing itching, skin irritation and dermal inflammation to host. The group Mallophaga has dorsoventrally flattened body and wingless parasitic insects of most of the orders of birds and mammals. The chewing lice have three suborders Amblycera, Ischnocera and Rhynchophthirina, of which the Amblycera are the most primitive group of chewing lice which are active and fast moving than group of lice 10,16-18. The Amblycera includes seven families: the Menoponidae, Laemobothriidae, Ricinidae, Boopiidae, Trimenoponidae, Gyropidae, and Abrocomophagidae ${ }^{10,11,19,20,24}$. The family Menoponidae is one of the oldest and largest family among all families of Amblycera. The family Menoponidae (Amblycera) consists of nine genera which are parasitizing world wide Afrimenopon, Myrsidea, Colpocephalum, Menacanthus, Menopon, Holomenopon, Heleonomus, Hohorstiella and Neokelerimenopon gen. nov. Both morphological and molecular phylogentic analysis supported the relationship among all menoponid genera ${ }^{14}$. It is a comparative study based on morphological characteristics of adult avian lice producing 50 characters from five species belonging to three genera and the cladogram of the grouped lice based on diversity and distribution of characters appears as a result of coevolution throughout the clade. By using both morphological and molecular ${ }^{5,6}$ data have studied the phylogenetics of amblycera. The classification of the family is relatively stable, but classification within this group upto the subfamily level has been difficult progressively ${ }^{10,14,19}$. The key to genera of Menoponidae ${ }^{9}$ covered only 15 genera with two main groups, Colpocephalum-complex and Menacanthus-complex. One of a taxonomist ${ }^{19}$ covered 35 menoponid genera and provided phylogenetic analysis of morphological characters to support four major groups of Menoponidae. Lice were studied ${ }^{18}$ by the classification and phylogeny of the Psocodea with reference to lice (Order Phthiraptera) the apomorphies of Psocodea and both Phthiraptera and Psocoptera were considered to be holophyletic group, but lies separately. Mallophagan lice should be important proof on the phylogeny of their hosts; three factors were discussed in the principle of host-parasite co-evolution, discontinuous distribution, secondary infestation and parallel evolution ${ }^{7,8}$. They also have considered the amblycera to be the most primitive lice, their ancestors may start to live as ectoparasitic of warm blooded animals in Triassic Period (225-190 million years ago) ${ }^{12,13,26}$. By 
the phylogenetic and cladistic analysis, it is believed that the chewing lice have evolved from an ancestral stock before the division into Anoplura and the Ischnocera, other that they diverged from those Ischnocera, which are already parasitic on mammals ${ }^{15,19,20}$.

The main purpose of the present study was to know Mallophagan fauna from the host birds of Hyderabad region and to see whether new facts thus obtained could contribute to the existing knowledge of the phylogeny. Unfortunately not a single family has been revised from this region. The morphological characters and characterstats have been derived from ${ }^{9,19}$. The line drawing of the specimens was made with the help of U-DA, Drawing tube attachment, fixed with Olympus Microscope (CH 20). The species diagram was made on the white paper sheet in which the whole mounts were drawn at 10 $X$ whereas the different parts of body of chewing lice were drawn at 100 to $400 X$. The diagram was traced on tracing paper sheet of $80 \mathrm{gm}$ with the help of water proof black ink using rotering pens of diameters of the nibs ranging from $0.5 \mathrm{~mm}$.

Key to the species of chewing lice of family menoponidae (amblycera) found on fowls of Hyderabad district, Sindh Pakistan 2,3,4.

1. Postpalpal process present; preocular groove in the formofslit

- Postpapal process absent; preocular groove in the formofknotch

2. Total length of female body $>2 \mathrm{~mm}$; pleural knots absent; head index 1.7or more; abdominal sternites with thicksetalbrushes

- Total length of female body $<2 \mathrm{~mm}$; pleural knots present; head index1.73; abdominal sternites with thinsetal brishes_-Menacanthus pallidulus

3. Body elongated and oblong; ocular nodi very weak to absent; female vulval margin narrow; male genitalia very a typical and peculiar in structure, genitalsacsclerite wing shaped, elongated

Menacanthus stramineus

- Body broader and oval; ocular nodi weakly present; female vulval margin broad; male genitalia typical of menoponid type, genitalial sac sclerite rod shaped, short inlength-

Menacanthus abdominalis

4. Ocular nodi and occipital nodi absent; oculooccipital carina absent; terminal segment of antennae globose; pleural ribs present; tergites complete, undivided; lateral setal brushes on terminalia of female absent; male abdomen bears thick, long tergalsetae in single row --------_-------------Menopon gallinae

- Ocular nodi and occipital nodi present; oculooccipital carina present; terminal segment of antennae elongated and oval; pleural ribs absent; tergites incomplete, III- VIII divided; lateral setal brushes on terminalia of female present; male abdomen bears thin, short tergal setae in double row-_Colpocephalum tausi

Cladistics analysis of chewing lice of fowls of family menoponidae upto generic level from Hyderabad, Sindh, Pakistan

\section{LIST OF CHARACTERS}

$A^{0}$ Anterior head margin thin andnarrow.

$\mathrm{A}^{1}$ Anterior head margin rounded, smooth and convex narrowly (Menopon)

$\mathrm{A}^{2}$ Anterior head margin rounded, smooth and convex broadly (Colpocephalum, Menacanthus)

$\mathrm{B}^{0}$ Preocular dorso-lateral margin of head wavy or sinuate.

$\mathrm{B}^{1}$ Preocular dorso-lateral margin of head bearing notch (Colpocephalum)

$\mathrm{B}^{2}$ Preocular dorso-lateral margin of head bearing slit (Menacanthus, Menopon)

$\mathrm{C}^{0}$ Temples small and condensed.

$\mathrm{C}^{1}$ Temples short and small (Menopon, Menacanthus)

$\mathrm{C}^{2}$ Temples long and quadrate(Colpocephalum)

$D^{0}$ DHS 8-11 Preocular setae not present.

$D^{1}$ DHS 8-11 Preocular setae present on margin (Colpocephalum, Menopon)

$D^{2}$ DHS 8-11 Preocular setae present on submargin (Menacanthu)

$E^{0}$ Dorsal Head Seta 9 notpresent.

$\mathrm{E}^{1}$ DHS 9 marginal in position (Colpocephalum, Menopon)

$\mathrm{E}^{2}$ DHS 9 submarginal in position (Menacanthus)

$\mathrm{F}^{0}$ Dorsal Head Seta 10 and Dorsal Head Seta 11 identical in length.

$\mathrm{F}^{1}$ Length of DHS 10 is more than DHS 11 (Menopon)

$\mathrm{F}^{2}$ Length of DHS 10 is less than DHS 11 (Colpocephalum, Menacanthus)

$\mathrm{G}^{0}$ DHS 19 and DHS 20 occular setae very long.

$\mathrm{G}^{1}$ DHS 19 longer than DHS 20 (Menopon, Menacanthus) 
$\mathrm{G}^{1}$ DHS 19 shorter than DHS 20 (Colpocephalum)

$\mathrm{H}^{0}$ DHS 21 and DHS 22 occipital setae absent.

$\mathrm{H}^{1}$ DHS 21 and DHS 22 occipital setae reaching upto pronotal carina (Colpocephalum)

$\mathrm{H}^{2}$ DHS 21 and DHS 22 occipital setae longer beyond pronotal carina and long macrosetae (Menopon, Menacanthus)

$I^{0}$ DHS 23 temporal setae undeveloped.

$I^{1}$ DHS 23 temporal setae are developed macrosetae (Colpocephalum, Menopon, Menacanthus)

$\mathrm{J}^{0}$ Dorsal Head Seta 23 spreadable with Dorsal Head Seta 22.

$\mathrm{J}^{1}$ DHS 23 is close with DHS 22 in straight line (Colpocephalum, Menopon, Menacanthus)

$\mathrm{K}^{0}$ Dorsal Head Seta 24 immature,condensed.

$\mathrm{K}^{1}$ DHS 24 is short, microseta (Colpocephalum, Menopon)

$\mathrm{K}^{2}$ DHS 24 is long macroseta(Menacanthus)

LDorsal Head Seta 26immature.

$\mathrm{L}^{1}$ DHS 26 is small, microseta (Colpocephalum, Menopon)

$\mathrm{L}^{2}$ DHS 26 is long, macroseta (Menacanthus)

$\mathrm{M}^{0}$ Alveoli of Dorsal Head Seta 26 distant from Dorsal Head Seta 27.

$M^{1}$ Alveoli of DHS 26 is separated from DHS 27 (Menacanthus)

$M^{2}$ Alveoli of DHS 26 and DHS 27 are contagious (Menopon, Colpocephalum)

$\mathrm{N}^{0}$ Dorsal Head Seta 29 terminal in position.

$\mathrm{N}^{1}$ DHS 29 is marginal in position (Menopon, Menacanthus)

$\mathrm{N}^{2}$ DHS 29 is submarginal in position (Colpocephalum)

$\mathrm{O}^{0}$ Occipital and ocular nodi absent.

$\mathrm{O}^{1}$ Occipital nodi is weakly developed only (Menacanthus, Menopon)

$\mathrm{O}^{2}$ Occipital and ocular nodi are well developed (Colpocephalum)

$\mathrm{P}^{0}$ Immature development of posterior part of maxillarypalpi.

$\mathrm{P}^{1}$ Absence of posterior part of maxillary palpi (Colpocephalum, Menopon)

$\mathrm{P}^{2}$ Presence of posterior part of maxillary palpi (Menacanthus)

$\mathrm{Q}^{0}$ Hypopharyngeal sclerite condensed.

$\mathrm{Q}^{1}$ Weakly development of hypopharyngeal sclerite (Menacanthus)
$\mathrm{Q}^{2}$ Well development of hypopharyngeal sclerite (Colpocephalum, Menopon)

$\mathrm{R}^{0}$ Gular plate not present.

$\mathrm{R}^{1}$ Weakly sclerotization of gular plate (Menopon, Menacanthus)

$\mathrm{R}^{2}$ Highly sclerotization of gular plate (Colpocephalum)

$\mathrm{S}^{0}$ Flagellomeres not as much of two segments.

$\mathrm{S}^{1}$ Flagellomeres are only one pair and present on segments, segments III and IV (Colpocephalum, Menacanthus, Menopon)

$\mathrm{T}^{0}$ Flagellomer II filiform.

$\mathrm{T}^{1}$ Enlarged and ovoid flagellomere II (Colpocephalum, Menopon)

$\mathrm{T}^{2}$ Rounded and globulated flagellomere II (Menacanthus)

$\mathrm{U}^{0}$ Ventro - lateral groove of antenna not present.

$\mathrm{U}^{1}$ Small and shallow ventro - lateral groove of antenna (Menacanthus)

$\mathrm{U}^{2}$ Small and narrow ventro - lateral groove of antenna (Colpocephalum)

$\mathrm{U}^{3}$ Largesizeandthinventro-lateral groove of antenna (Menopon)

$\mathrm{V}^{0}$ Ventro - lateral marginal setae arranged anterior termination not present.

$\mathrm{V}^{1}$ Ventro - lateral marginal setae is present on anterior termination and one small and one large size (Menopon, Menacanthus, Colpocephalum)

$\mathrm{W}^{0}$ Transverse pronotal carina is notpresent.

$\mathrm{W}^{1}$ Transverse pronotal carina is weak (Menacanthus, Menopon)

$\mathrm{W}^{2}$ Transverse pronotal carina is strong(Colpocephalum)

$X^{0}$ Posterior pronotal setal row half-finished.

$\mathrm{X}^{1} \mathrm{Posterior}$ pronotal setal row is complete (Menopon, Menacanthus, Colpocephalum)

$\mathrm{Y}^{0}$ Postnotum on pronotum absent.

$\mathrm{Y}^{1}$ Postnotum on pronotum is always present (Menopon, Colpocephalum, Menacanthu)

$Z^{0} 2^{\text {nd }}$ seta of metanotal termainal setal row elongated macro setae.

$Z^{1}$ Development of $2^{\text {nd }}$ seta of metanotal terminal setal row as surface seta (Colpocephalum)

$Z^{2}$ Development of pin like or plucky $2^{\text {nd }}$ seta of metanotal terminal setal row which is smaller than surface seta (Menacanthus,Menopon)

$A A^{0}$ Not presence of prosternal plate. 
$\mathrm{AA}^{1}$ Weakly development of prosternal plate (Colpocephalum, Menacanthus, and Menopon)

$\mathrm{BB}^{0}$ Anterior setae continuously Prosternal plate not presents.

$\mathrm{BB}^{1}$ Anterior setae are present and close to the prosternal plate (Menopon, Menacanthus)

$\mathrm{BB}^{2}$ Anterior setae are present and away from the prosternal plate (Colpocephalum)

$\mathrm{CC}^{0}$ Ordinary prosternal plate lateral margins.

$\mathrm{CC}^{1}$ Reduced and clear prosternal plate lateral margins (Colpocephalum, Menopon)

$\mathrm{CC}^{2}$ Unclar development of prosternal plate lateral margins (Menacanthus)

$\mathrm{DD}^{0}$ Posterior margin of prosternal plate notpresent.

DD ${ }^{1}$ Convex prosternal plate posterior margin (Menopon, Menacanthus, Colpocephalum)

$\mathrm{EE}^{0}$ Metasternal plate not present.

$E^{1}$ Weakly development of metasternal plate (Menopon)

$E^{2}$ Well development of metasternal plate (Colpocephalum, Menacanthus)

FFOAbsence of setae on femurlll.

$\mathrm{FF}^{1}$ Thin brushes of setae are present on its venter of femur III (Menopon)

$\mathrm{FF}^{2}$ Thick brushes of setae are present on its venter of femur III (Menacanthus)

$\mathrm{FF}^{3}$ Combs of setae are present on its venter of femur III (Colpocephalum)

$\mathrm{GG}^{0}$ Immature female tergites.

$\mathrm{GG}^{1}$ Undivided and complete female tergites (Menacanthus, Menopon)

$\mathrm{GG}^{2}$ Division of female tergites into two or three parts (Colpocephalum)

$\mathrm{HH}^{0}$ Posterior row of tergal setae notpresent. (Menopon)

$\mathrm{HH}^{1}$ Presence of one row of tergal setae posteriorly

$\mathrm{HH}^{2}$ Presence of two rows of tergal setae posteriorly (Colpocephalum, Menacanthus)

$1{ }^{0}$ Pleural spiracles in particular position.

${ }^{1}{ }^{1}$ Particular position of tergal spiracles is occured (Colpocephalum, Menopon, Menacanthus)

$\mathrm{JJ}^{0}$ Postspiracular setae not present.

$\mathrm{JJ}^{1}$ Postspiracular setae is present posterior to spiracles (Menopon, Menacanthus)

$\mathrm{JJ}^{2}$ Postspiracular setae is present latero - posterior to spiracles (Colpocephalum)

$\mathrm{KK}^{0}$ Sternites of abdomen are withoutsetae.
$\mathrm{KK}^{1}$ Sternites of abdomen are with brushes of setae (Menacanthus, Menopon)

$\mathrm{KK}^{2}$ Sternites of abdomen are with ctenidia (Colpocephalum)

$\mathrm{LL}^{0}$ Arrangement of seta on sternites III - V.

$\mathrm{LL}^{1}$ Arrangement of seta on sternites III only (Colpocephalum)

$\mathrm{LL}^{2}$ Arrangement of seta on sternitesIII and IV (Menopon)

$\mathrm{LL}^{3}$ Arrangement of seta on sternites IV and $\mathrm{V}$ (Menacanthus)

$\mathrm{MM}^{0}$ Irregular or patchy appearance of sternal setal brushes.

$\mathrm{MM}^{1}$ Weakly development of sternal setal brushes (Menopon)

$\mathrm{MM}^{2}$ Well development of sternal seta brushes (Menacanthus)

$\mathrm{NN}^{0}$ Many numbers of sternal ctenidia.

$\mathrm{NN}^{1}$ Presence of three pairs of sternal ctenidia (Colpocephalum)

$\mathrm{NN}^{2}$ Presence of more than three or additional pairs of sternal ctenidia (Menacanthus and Menopon)

$\mathrm{OO}^{0}$ Subgenital plate of female is withoutsetae.

$\mathrm{OO}^{1}$ Subgenital plate of female is bearing shortl and stout setae (Menopon)

$\mathrm{OO}^{2}$ Subgenital plate of female is bearing short and fine setae (Menacanthus)

$\mathrm{OO}^{3}$ Subgenital plate of female is bearing elongated thick setae (Colpocephalum)

$\mathrm{PP}^{0}$ Female Anal margin is without setal fringe.

$\mathrm{PP}^{1}$ Female anal margin is furnished with fringe of small and stout setae (Menopon)

$\mathrm{PP}^{2}$ Female anal margin is furnished with fringe of small and fine setae (Menacanthus)

$\mathrm{PP}^{3}$ Female anal margin is furnished with fringe of elongated and thick setae (Colpocephalum)

$\mathrm{QQ}^{0}$ External genitalia of male very lengthy reaching upto the segment IV.

$\mathrm{QQ}^{1}$ External genitalia of male is large size, reaching upto to the segment IV (Menacanthus, Menopon, Colpocephalum)

$\mathrm{RR}^{0}$ Framework of male genitalia is verycondensed.

$\mathrm{RR}^{1}$ Framework of male genitaliais simple or modest (Colpocephalum, Menopon)

$\mathrm{RR}^{2}$ Framework of male genitalia is complex or typical and very unique (Menacanthus) 
Cladistic Analysis of Species Infesting (Amblycera: Menoponidae) Fowls of District Hyderabad, Sindh, Pakistan

TABLE-1 : Raw Data Matrix Chart for character and characterstates of the three genera of family Menoponidae (Amblycera) collected from fowls.

\begin{tabular}{|c|c|c|c|}
\hline Characters & Colpocephalum & Menacanthus & Menopon \\
\hline Head Anterior Margin $(A)$ & 2 & 2 & 1 \\
\hline Head Dorso-lateral Margin (B) & 1 & 2 & 2 \\
\hline Structure of Tamples (C) & 2 & 1 & 1 \\
\hline Preocular Setae DHS 8-11 (D) & 1 & 2 & 1 \\
\hline Position of DH9 (E) & 1 & 2 & 1 \\
\hline Length of DHS 10 and $11(F)$ & 2 & 2 & 1 \\
\hline Ocular Setae 21 and $22(H)$ & 1 & 2 & 2 \\
\hline Ocular setae Dorsal Head Seta 19 and 20 (G) & 1 & 2 & 1 \\
\hline Temporal Seta DHS 23 (I) & 1 & 1 & 1 \\
\hline Position of DHS $23(\mathrm{~J})$ & 1 & 1 & 1 \\
\hline Nature of DHS $24(K)$ & 1 & 2 & 1 \\
\hline Nature of DHS $26(\mathrm{~L})$ & 1 & 2 & 1 \\
\hline Alveoli of DHS 26 and DHS 27 (M) & 2 & 1 & 2 \\
\hline Position of DHS $29(\mathrm{~N})$ & 2 & 1 & 1 \\
\hline Ocular and Occipital Nodi (O) & 2 & 1 & 1 \\
\hline Postpalpal Processes (P) & 1 & 2 & 1 \\
\hline Hypopharygeal Sclerite (Q) & 2 & 1 & 2 \\
\hline Gular Plate (R) & 2 & 1 & 1 \\
\hline Number of Flagellomeres (S) & 1 & 1 & 2 \\
\hline Structure of Flagellomere II ( $\mathrm{T})$ & 1 & 2 & 1 \\
\hline Ventro-lateral Antennal Groove (U) & 2 & 1 & 3 \\
\hline Setae on Ventro-lateral Margins (V) & 1 & 1 & 1 \\
\hline Transverse Pronotal Carina (W) & 2 & 1 & 1 \\
\hline
\end{tabular}


Farheen Shaikh, Saima Naz and Nadir Ali Birmani

\begin{tabular}{|c|c|c|c|}
\hline Characters & Colpocephalum & Menacanthus & Menopon \\
\hline Pronotal Setal Row Posterirly (X) & 1 & 1 & 1 \\
\hline Postnotum on Pronotum (Y) & 2 & 1 & 1 \\
\hline $2^{\text {nd }}$ Seta of Terminal Row of Metanotum (Z) & 1 & 2 & 2 \\
\hline Prosternal Plate (AA) & 1 & 1 & 1 \\
\hline Prosternal Setae (BB) & 2 & 1 & 1 \\
\hline Prosternal Plate Lateral Margin (CC) & 2 & 1 & 2 \\
\hline Prosternal Plate Posterior Margin (DD) & 1 & 1 & 1 \\
\hline Metasternal Plate (EE) & 1 & 1 & 2 \\
\hline Chaetotaxy of Femur III (FF) & 3 & 2 & 1 \\
\hline Female Abdominal Tergites (GG) & 2 & 1 & 1 \\
\hline Posterior Row of Tergal Setae $(\mathrm{HH})$ & 2 & 2 & 1 \\
\hline Position of Abdominal Spiracles (II) & 1 & 1 & 1 \\
\hline Postspiracular Seta (JJ) & 2 & 1 & 1 \\
\hline Abdominal Sternites Chaetotaxy (KK) & 2 & 1 & 1 \\
\hline Arrangement of Setae on Sternites III-V (LL) & 1 & 3 & 2 \\
\hline Condition of Sternal Brushes (MM) & 2 & 2 & 1 \\
\hline Number on Sternal Ctenidia (NN) & 1 & 2 & 2 \\
\hline Female subgenital Plate $(\mathrm{OO})$ & 3 & 2 & 1 \\
\hline Female Annal Margin (PP) & 3 & 2 & 1 \\
\hline Length of External Genitalia of Male(QQ) & 1 & 1 & 1 \\
\hline Male Genitalia Framework (RR) & 1 & 2 & 1 \\
\hline Nature of Basal Apodeme (SS) & 2 & 1 & 3 \\
\hline Structure of Parameres (TT) & 1 & 2 & 2 \\
\hline $\begin{array}{l}\text { Position of Both Ends of Parameres and } \\
\text { Endomeres posteriorly(UU) }\end{array}$ & 1 & 2 & 2 \\
\hline
\end{tabular}


$\mathrm{SS}^{0}$ Absence of basal apodeme.

$\mathrm{SS}^{1}$ Well sclerotized and wide basal apodeme(Menacanthus)

$\mathrm{SS}^{2}$ Weakly sclerotized and narrow basal apodeme (Colpocephalum)

$\mathrm{SS}^{3}$ Reduced and undeveloped basal apodeme is (Menopon)

$\mathrm{TT}^{0}$ Parameres condensed.

$\mathrm{TT}^{1}$ Parameres is small, stout and straight (Colpocephalum)

$\mathrm{TT}^{2}$ Parameres is convex and outward (Menopon, Menacanthus)

$\mathrm{UU}^{0}$ Both margins of parameres and endomeres are parallel posteriorly.

$\mathrm{UU}^{1}$ Margin of parameres ends is smaller posteriorly than margin of endomeres ends (Colpocephalum)

UU²Margin of parameres ends is larger Posteriorly than margin of endomeres ends (Menacanthus,Menopon)

\section{CHARACTER STATES AND ANALYSIS}

\section{Head Anterior Margin (A)}

Head anterior margin thin, smooth, rounded and convex narrowly in Menopon which shows its autapomorphic condition $\left(A^{1}\right)$, while in Colpocephalum and Menacanthus, the head anterior margin is smooth and convex broadly, which is showing their synapomorphic condition $\left(A^{2}\right)$.

\section{Head Dorso -lateral Margin (B)}

Head dorso -lateral margins in Colpocephalum, is bearing preocular notch which shows its autapomorphic condition $\left(\mathrm{B}^{1}\right)$, while in Menacanthusand Menopon, the head dorso-lateral margins is bearing preocular slit, which is showing their synapomorphic condition $\left(\mathrm{B}^{2}\right)$.

\section{Strucutre of Temples (C)}

Temples in Menopon and Menacanthus, are short and smooth, which shows their synapomorphic condition $\left(C^{1}\right)$, while in Colpocephalum, the temples are long and quadrate, which is showing its autapomorphic condition $\left(\mathrm{C}^{2}\right)$.

\section{Preocular Setae Dorsal Head Setae 8 to 11 (D)}

The preocular setae DHS 8 to 11 in Menopon and Colpocephalum, present on margin which is showing their synapomorphic condition $\left(D^{1}\right)$, while in Menacanthus, the preocular setae DHS 8 to 11 present permanently on submargin, which is showing its autapomorphic condition $\left(D^{2}\right)$.

\section{Positions of Dorsal Head Seta 9(E)}

DHS 9 in Colpocephalum, Menopon, is marginal in position, which shows their synapomorphic condition $\left(E^{1}\right)$, while in Menacanthus the DHS 9 is small and submarginal in position, which is showing its autapomorphic condition $\left(\mathrm{E}^{2}\right)$.

\section{Length of Dorsal Head Setae 10 and 11 (F)}

Length of DHS 10 in Menopon, is more than DHS 11 , which is showing its autapomorphic condition $\left(\mathrm{F}^{1}\right)$, while in Colpocephalum and Menacanthus theDHS 10 is smaller than DHS 11 , which is showing their synapomorphic condition $\left(\mathrm{F}^{2}\right)$.

\section{Ocular setae Dorsal Head Seta 19 and 20(G)}

Ocular setae in Colpocephalum, DHS 19 is longer than DHS 20 are present, which shows its autapomorphic condition $\left(\mathrm{G}^{1}\right)$, while in Menopon and Menacanthus, the Ocular setae DHS 19 is smaller than DHS 20 are evident, which is showing their synapomorphic condition $\left(\mathrm{G}^{2}\right)$.

\section{Occipital Setae 21 and $22(\mathrm{H})$}

Occipital setae in Colpocephalum, DHS 21 and 22 are reaching upto the pronotal carina, which is showing its autapomorphic condition $\left(\mathrm{H}^{1}\right)$, whilein Menacanthus and Menopon, DHS 21 and 22 large sizes beyond pronotal carina and large macrosetae, which shows their syanpomorphic condition $\left(\mathrm{H}^{2}\right)$.

\section{Temporal Seta Dorsal Head Seta 23 (I)}

Temporal seta in Colpocephalum, Menopon and Menacanthus, DHS 23 is very developed macroseta, which is showing their synapomorphic condition $\left(\mathrm{I}^{1}\right)$.

\section{Position of Dorsal Head Seta 23 (J)}

DHS 23 in Colpocephalum, Menacanthus and Menopon, is close with DHS 22, which is showing their synapomorphic condition $\left(\mathrm{J}^{1}\right)$.

\section{Nature of Dorsal Head Seta 24(K)}

DHS 24 in Colpocephalum and Menopon, is short, microseta, which is showing their synapomorphic condition $\left(\mathrm{K}^{1}\right)$, while in Menacanthus, DHS 24 is long macroseta, which is showing its autapomorphic condition $\left(\mathrm{K}^{2}\right)$.

\section{Nature of Dorsal Head Seta 26(L)}

DHS 26 in Colpocephalum and Menopon, is small microseta, which is showing their synapomorphic condition $\left(L^{1}\right)$, while in Menacanthus, DHS 26 is long macroseta, which is showing its autapomorphic condition $\left(\mathrm{L}^{2}\right)$.

\section{Alveoli of Dorsal Head Setae 26 and DHS 27 (M)}

The alveoli of DHS 26 and DHS 27 in Menacanthus, are separated from each one other, which shows its autapomorphic condition $\left(\mathrm{M}^{1}\right)$, while in Menopon and Colpocephalum, the alveoli of DHS 26 and DHS 27 are 


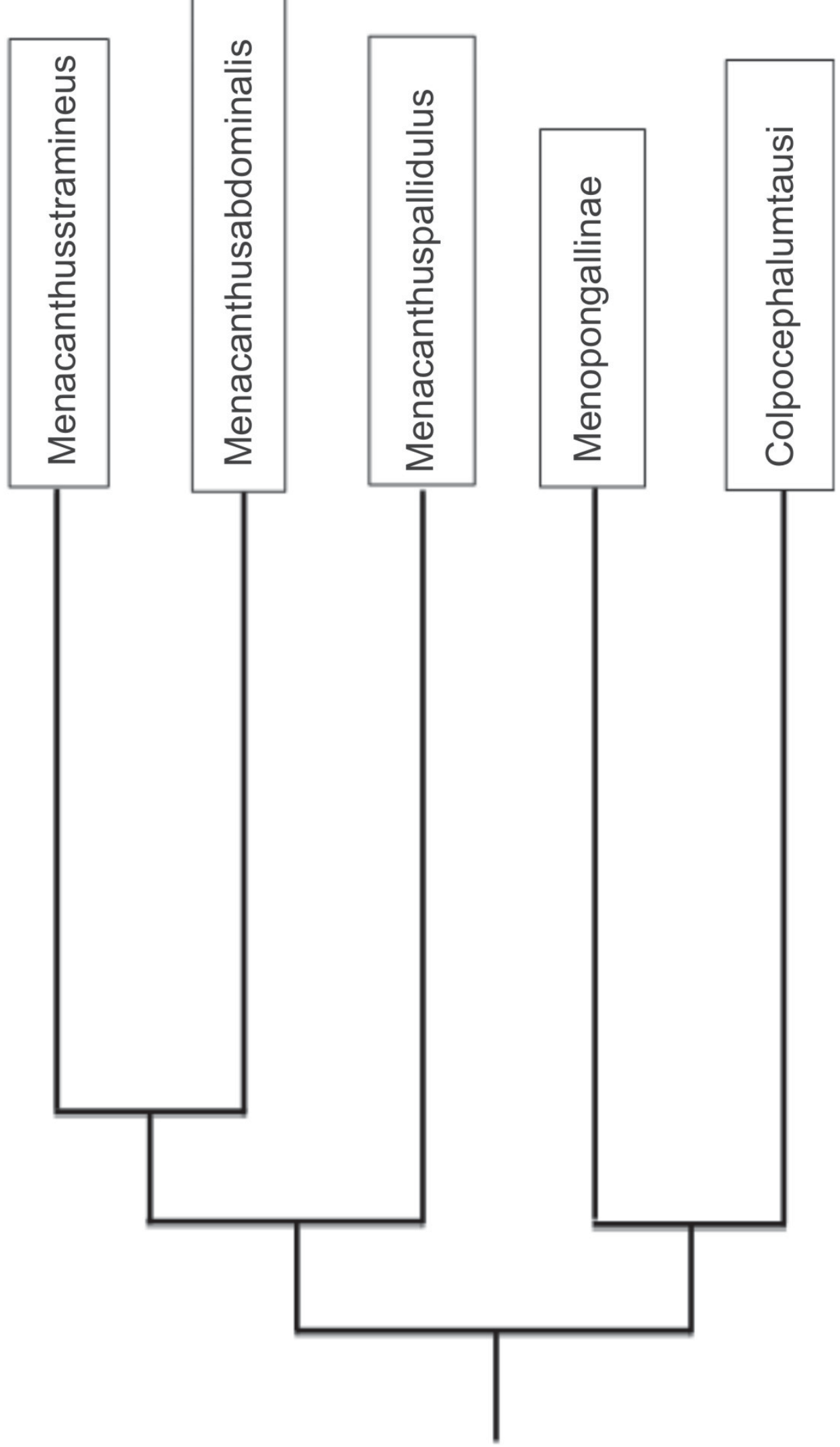

Fig. 1 : Cladogram of the genera of Family Menoponidae collected from Fowls in District Hyderabad, Sindh, Pakistan, showing their phylogenetic relationship. 
contagious, which is showing their synapomorphic condition $\left(\mathrm{M}^{2}\right)$.

\section{Position of Dorsal Head Seta 29 (N)}

DHS 29 in Menopon and Menacanthus, is marginal in position, which is showing their synapomorphic condition $\left(\mathrm{N}^{1}\right)$, while in Colpocephalum, the DHS 29 is slightly submarginal in position, which is showing its autapomorphic condition $\left(\mathrm{N}^{2}\right)$.

\section{Ocular and Occipital Nodi (O)}

Occipital nodi in Menopon and Menacanthus, is weakly developed only, which is showing their synapomorphic condition $\left(\mathrm{O}^{1}\right)$, while in Colpocephalum, the well development of ocular and occipital nodi, which is showing its autapomorphic condition $\left(\mathrm{O}^{2}\right)$.

\section{Postpalpal Processes (P)}

Postpalpal processes in Menopon and Colpocephalum, are not present, which is showing their synapomorphic condition $\left(\mathrm{P}^{1}\right)$, while in Menacanthus, the postpalpal prosesses are present, which is showing its autapomorphic condition $\left(\mathrm{P}^{2}\right)$.

\section{Hypopharyngeal Sclerite(Q)}

Weakly development of hypopharyngeal sclerite in Menacanthus, which shows its autapomorphic condition $\left(\mathrm{Q}^{1}\right)$, while in Colpocephalum and Menopon, the well development of hypopharyngeal sclerite, which is showing their synapomorphic condition $\left(\mathrm{Q}^{2}\right)$.

\section{Gular Plate (R)}

Gular plate in Menacanthus and Menopon, is weakly developed, whichis showing their synapomorphic condition $\left(\mathrm{R}^{1}\right)$, while in Colpocephalum, thegularplate is well developed and completely sclerotized, whic shows its autapomorphic condition $\left(\mathrm{R}^{2}\right)$.

\section{Number of Flagellomeres(S)}

Flagellomeres in Colpocephalum, Menacanthus and Menopon, are only one pair, which is showing their synapomorphic condition $\left(\mathrm{S}^{1}\right)$.

\section{Structure of Flagellomere II (T)}

Enlarged and ovoid structure of flagellomere II in Colpocephalum and Menopon, which is showing their synapomorphic condition $\left(\mathrm{T}^{1}\right)$, while in Menacanthus, the rounded and globulated structure of flagellomere II is present, which shows its autapomorphic condition $\left(\mathrm{T}^{2}\right)$.

\section{Ventro-lateral Groove of Antenna (U)}

The ventro-lateral groove of antenna in Menacanthus, is small and little deep, which shows its autapomorphic condition $\left(\mathrm{U}^{1}\right)$, while in Colpocephalum, the ventro-lateral antennal groove is small and narrow, which is showing its autapomorphic condition $\left(U^{2}\right)$, while in Menopon, the ventro-lateral groove is large and thin, which shows its autapomorphic condition $\left(\mathrm{U}^{3}\right)$.

\section{Setae on Ventro-lateral Margins (V)}

Ventro-lateral marginal setae in Colpocephalum, Menacanthus and Menopon, present on anterior termination, one small and one large size, which is showing their synapomorphic condition $\left(\mathrm{V}^{1}\right)$.

\section{Transverse Pronotal carina (W)}

Transverse pronotal carina in Colpocephalum, Menacanthus and Menopon, is present and sclerotized, which is showing their autapomorphic condition $\left(\mathrm{W}^{1}\right)$.

\section{Pronotal Setal Row Posteriorly (X)}

Pronotal setal row posteriorly in Colpocephalum, Menacanthus and Menopon, is complete, which is showing their autapomorphic condition $\left(\mathrm{X}^{1}\right)$.

\section{Postnotum on Pronotum (Y)}

Postnotum in Colpocephalum, Menacanthus and Menopon, is always present, which is showing their autapomorphic condition $\left(\mathrm{Y}^{1}\right)$.

\section{$2^{\text {nd }}$ Seta of terminal Row of Metanotum (Z)}

Development of $2^{\text {nd }}$ seta of terminal row of metanotum in Colpocephalum, which shows its autapomorphic condition $\left(Z^{1}\right)$, while in in Menopon and Menacanthus, development of pin like or plucky $2^{\text {nd }}$ seta of terminal row of metanotum which is smaller than the surface seta1, showing their synapomorphic condition $\left(Z^{2}\right)$.

\section{Prosternal Plate (AA)}

Prosternal plate in Colpocephalum, Menopon and Menacanthus, is weakly developed, which is showing their autapomorphic condition $\left(A A^{1}\right)$.

\section{Prosternal Setae (BB)}

The anterior prosternal setae in Menacanthus, Menopon, is present near to the plate, which shows their autapomorphic condition $\left(\mathrm{BB}^{1}\right)$, while in Colpocephalum, the anterior prosternal setae is situated away from the plate, which shows its synapomorphic condition $\left(\mathrm{BB}^{2}\right)$.

\section{Prosternal Plate Lateral Margin (CC)}

Prosternal plate lateral margin in Colpocephalum and Menopon, are reduced and clear, which is showing their autapomorphic condition $\left(\mathrm{CC}^{1}\right)$, while in Menacanthus, the prosternal plate lateral margin are unclear, which is showing its synapomorphic condition $\left(\mathrm{CC}^{2}\right)$.

\section{Prosternal Plate Posterior Margin (DD)}

The prosternal plate posterior margin in Menopon, Colpocephalum and Menacanthus, is convex, which is showing their autapomorphic condition (DD $\left.{ }^{1}\right)$. 


\section{Metasternal Plate (EE)}

Weakly development of metasternal plate in Menopon, which is showing its autapomorphic condition $\left(\mathrm{EE}^{1}\right)$, while in Menacanthus, Colpocephalum, the welldevelopment of metasternal plate, which is showing their synapomorphic condition(EE $\left.{ }^{2}\right)$.

\section{Chaetotaxy of Femur III (FF)}

Presence of small brushes of setae on its venter of femur III in Menopon, which shows its autapomorphic condition ( $\mathrm{FF}^{1}$ ), while in Menacanthus, the presence of thick brushes of setae on its venter of femur III, which is showing its synapomorphic condition $\left(\mathrm{FF}^{2}\right)$, while in Colpocephalum, the evidenceof ctenidia on its venter of femur III, which is showing its derived synapomorphic condition $\left(\mathrm{FF}^{3}\right)$.

\section{Female Abdominal Tergites (GG)}

Female abdominal tergites in Menopon and Menacanthus, are broad, complete and undivided, which shows their autapomorphic condition $\left(\mathrm{GG}^{1}\right)$, while in Colpocephalum, the female abdominal tergites are divided medially or laterally, which is showing its synapomorphic condition $\left(G^{2}\right)$.

\section{Posterior Row of Tergal Setae (HH)}

There is one row of posterior tergal setae in Menopon, which shows its autapomorphic condition $\left(\mathrm{HH}^{1}\right)$, while in in Menacanthus and Colpocephalum, there are two rows of posterior tergal setae, which is showing their synapomorphic condition $\left(\mathrm{HH}^{2}\right)$.

\section{Position of Abdominal Spiracles (II)}

The abdominal spiracles in Colpocephalum, Menopon and Menacanthus, are always tergal in position, which is showing their autapomorphic condition $\left(\mathrm{II}^{1}\right)$.

\section{Postspiracular Seta (JJ)}

The postspiracular seta in Menopon and Menacanthus, is posterior to spiracles, which is showing their autaapomorphic condition $\left(\mathrm{JJ}^{1}\right)$, while in Colpocephalum, the postspirscular seta is latero-posterior to the spiracles, which is showing its synapomorphic condition $\left(\mathrm{JJ}^{2}\right)$.

\section{Abdominal Sternites Chaetotaxy (KK)}

Abdominal sternites in Menopon and Menacanthus, are with setal brushes, which is showing their autapomorphic condition $\left(\mathrm{KK}^{1}\right)$, while in Colpocephalum, the abdominal sternites are with ctenidia, which is showing its syntapomorphic condition $\left(\mathrm{KK}^{2}\right)$.

\section{Arrangement of Setae on Sternites III-V (LL)}

Arrangement of setae in Colpocephalum, on only sternites III, which shows its autapomorphic condition
$\left(L L^{1}\right)$, while in Menopon, arrangement of setae on sternite III and IV, which is showing its synapomorphic condition $\left(L L^{2}\right)$, while in Menacanthus, the arrangement of setae on sternites IV and V, which is showing its derived synapomorphic condition $\left(\mathrm{LL}^{3}\right)$.

\section{Condition of Sternal Setal Brushes(MM)}

Thin and weakly development of sternal setal brushes in Menopon, which shows its autapomorphic condition $\left(\mathrm{MM}^{1}\right)$, while in Colpocephalum and Menacanthus, the thick and well development of sternal setal brushes, which is showing their synapomorphic condition $\left(\mathrm{MM}^{2}\right)$.

\section{Number on Sternal Ctenidia (NN)}

Presence of three sternal ctenidia in Colpocephalum, which shows its autapomorphic condition $\left(\mathrm{NN}^{1}\right)$, while in Menacanthus, Menopon, presence of more than three sternal ctenidia, which is showing its synapomorphic condition ( $\left.\mathrm{NN}^{2}\right)$.

\section{Subgenital Plate of Female (OO)}

The subgenital plate of female in Menopon, is short and stout, which shows its autapomorphic condition $\left(\mathrm{OO}^{1}\right)$, while in Menacanthus, the subgenital plate of female bears short and fine setae, which is showing its synapomorphic condition $\left(\mathrm{OO}^{2}\right)$. While in Colpocephalum, the subgenital plate of female is furnished with large and thick setae, which is showing its derived synapomorphic condition $\left(\mathrm{OO}^{3}\right)$.

\section{Female Annal Margin (PP)}

The female anal margin in Menopon, is furnished with fringe of small, stout setae, which is showing its autapomorphic condition $\left(\mathrm{PP}^{1}\right)$, while in Menacanthus, the female anal margin is furnished with fringe of small and fine setae, which is showing its synapomorphic condition $\left(\mathrm{PP}^{2}\right)$, while in Colpocephalum, the female anal margin is furnished with fringe of large size and thick setae, which is showing its derived synapomorphic condition $\left(\mathrm{PP}^{3}\right)$.

\section{Length of External Genitalia of Male (QQ)}

External genitalia of male in Menopon, Colpocephalum and Menacanthus, are moderate to large size and reaching up to abdominal segment IV, which is showing their autapomorphic condition $\left(\mathrm{QQ}^{1}\right)$.

\section{Framework of Male Genitalia (RR)}

Framework of male genitalia in Colpocephalum and Menopon is simple or modest, which shows their autapomorphic condition $\left(R R^{1}\right)$, while in Menacanthus, the framework of male genitalia is complex, or characteristic, and very unique, which is showing its synapomorphic condition $\left(\mathrm{RR}^{2}\right)$. 

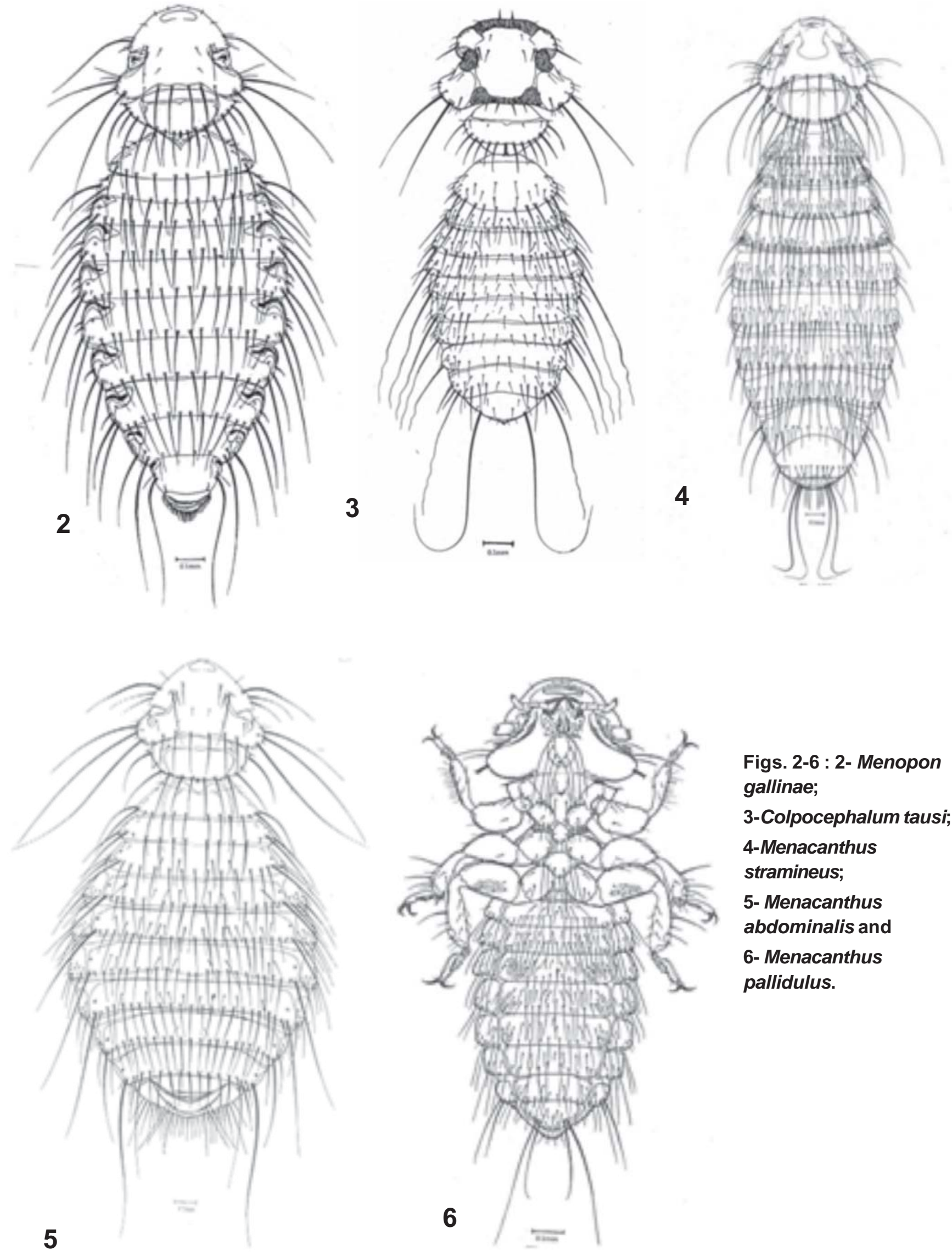

Figs. 2-6 : 2- Menopon gallinae; 3-Colpocephalum tausi; 4-Menacanthus stramineus; 5- Menacanthus abdominalis and 6-Menacanthus pallidulus. 


\section{Nature of Basal Apodeme (SS)}

The wide and well sclerotization of basal apodeme in Menacanthus, which is showing its autapomorphic condition $\left(\mathrm{SS}^{1}\right)$, while in Colpocephalum, the thin and weakly sclerotization of basal apodeme, which shows its synapomorphic condition (SS ${ }^{2}$ ), while in Menopon, the presence of reduced and undeveloped basal apodeme, which is showing its derived synapomorphiccondition $\left(\mathrm{SS}^{3}\right)$.

\section{Structure of Parameres (TT)}

Parameres in Colpocephalum, are small, stout and straight, which shows its autapomorphic condition ( $\left.\mathrm{TT}^{1}\right)$, while in Menopon and Menacanthus, the parameres are highly curve outward, which is showing their synapomorphic condition ( $\left.\mathrm{TT}^{2}\right)$.

\section{Position of Both Ends of Parameres and Endomeres Posteriorly (UU)}

Parameres posterior end is smaller in Colpocephalum, than endomeres posterior margin, which is showing its autapomorphic condition $\left(U U^{1}\right)$, while in Menacanthus and Menopon, the parameres posterior end longer than endomere posterior end, which is showing their synapomorphic condition $\left(\mathrm{UU}^{2}\right)$.

Position of Both Ends of Parameres and Endomeres Posteriorly (UU) Parameres posterior end is smaller in Colpocephalum, than endomeres posterior margin, which is showing its autapomorphic condition $\left(U U^{1}\right)$, while in Menacanthus and Menopon, the parameres posterior end longer than endomere posterior end, which is showing their synapomorphic condition $\left(\mathrm{UU}^{2}\right)$.

\section{Discussion}

Family Phasianidae (Aves: Galliformes) is a large family, of the avian order Galliformes includes pheasants, domestic fowls, patridges quails (Batairs), red jungle fowls, turkey fowls, pea fowls and guinea fowls. The birds are also known as game fowls with three pairs of clasping types of legs terminating to one or two tarsal claws ${ }^{25}$. The birds have heavy body, moderate to large size are common in our region and are mostly kept in captivity by humans and provide them natural environment. The family Menoponidae (Amblycera) consists of nine genera which are parasitizing avian fauna worldwide, these genera are Afrimenopon, Myrsidea, Colpocephalum, Menacanthus, Menopon, Holomenopon, Heleonomus, Hohorstiella and Neokelerimenopon gen. nov. During present investigation, 05 species of family Menoponidae were recovered which are Menacanthus stramineus, Menacanthus pallidulus, Menacanthus abdominalis, Menopon gallinae and Colpocephalum tausi ${ }^{4}$. The cladogram of amblycera species shows that $M$. stramineus and $M$. pallidulus are the sister group I, outgroup I of sister group I includes $M$. gallinae and C. tausi. The sister group II consist of $M$. stramineus and $M$. abdominalis, outgroup II of sister group Il includes M. pallidulus and M. gallinae (Fig. 1). Presently included appear to fall into two groups (Fig. 1). Group I includes Menacanthus stramineus, Menacanthus abdominalis and Menacanthus pallidulus which appear to be closely related and play sister group relationship to each other by having apomorphies of head which is circumfasciate, postpalpal process developed, preocular grooves in the form of slit, body elongated, oval and oblong, ocular nodi weakly present, abdominal sternites with setal brushes, male genitalia is typical with genital sac sclerites and female vuval margin is broad. The group II further consisting of two subgroups. Subgroup I comprises of Menopon gallinae which appear to be closely related and play sister group relationship to each other by having apomorphies of DHS 8-11 preocular setae are present on margin $\left(D^{1}\right)$, DHS 9 marginal in position $\left(E^{1}\right)$, DHS 24 Small and microseta $\left(\mathrm{K}^{1}\right)$, alveoli of DHS 26 touching the alveoli of DHS $27\left(\mathrm{M}^{2}\right)$, Dorsal head sensillae a-c present $\left(\mathrm{O}^{2}\right)$, posterior part of maxillary palpi not developed into postpalpal process $\left(\mathrm{Q}^{1}\right)$, hypopharyngeal sclerite well developed $\left(R^{2}\right)$. The subgroup II comprises of Colpocephalum tausi which appear to be closely related and play sister group relationship to each other by having apomorphies of flagellomere II oval and elongated $\left(\mathrm{U}^{1}\right)$, posterior pronotal setal row complete $\left(\mathrm{Y}^{1}\right)$, prosternal plate is weakly developed $\left(\mathrm{BB}^{1}\right)$, lateral margins of prosternal plate reduced $\left(\mathrm{DD}^{1}\right)$, spiracles tergal in position $\left(\mathrm{KK}^{1}\right)$, male external genitalia moderate to long , extending up to the segment IV $\left(\mathrm{QQ}^{1}\right)$ and male genitalia armature simple or modest $\left(\mathrm{RR}^{1}\right)$.

Chewing lice are the source of mechanically damage to host body, exasperate, because irritating, and swelling, and also cause bacterial or viral diseases, and in some circumstances, they become the source of the death of young to old birds. The information about the infestation caused by parasitic insects chewing lice in birds, exposed that there are more than hundreds species harboring in birds, have got unlimited, monetary, commercial, financial, ecologically, and health value. The chewing lice of Phasianid birds have studied, in different parts of the world $2,3,7,9,19,20$ but in Pakistan there is no thorough study on chewing lice especially of fowls in Hyderabad Sindh, Pakistan. The review of literature revealed that some work has been done on the chewing lice particularly in the province of Sindh ${ }^{21-23}$ however, sporadic investigations were carried out in Faisalabad (Punjab) before partition of indo- pak region ${ }^{1-3}$. The cladistic relationship of chewing lice species was analyzed to understand the evolutionary aspect of their morphologies as well as their host specificity by using the key 
characters of lice. This is the first investigation of its kind on various types and breeds of fowls from Sindh, Pakistan, made a valuable contribution to the chewing lice fauna of Pakistan.

\section{References}

1. Ansari MAR. Mallophaga found on domestic fowl Gallus domesticus Linnaeus, in the Punjab, Indian J. Entomol. 1943; 5 (1-2), 129-142.

2. Ansari MAR. Mallophaga found on Domestic fowl Gallus domesticus Linnaeus, in the Punjab, Indian J. Entomol. 1943; 5 (1 -2): 129-142, figs. 9.

3. Ansari MAR. Mallophaga (Ischnocera) infesting birds in the Punjab (India), Proc. Nat. Inst. Sci. India. 1947; 13 (6): 253-303.

4. Ansari MAR. Mallophaga (Amblycera) infesting birds in the Punjab (India), Proc. Nat. Inst. Sci. India. 1951;17 (2): 127-203.

5. Barker SC. Phylogeny of the Heterodoxusoctoseriatus group (Phthiraptera: Boopiidae) from rock-wallabies (Marsupialia: Petrogale), Sytematic Parasitology. 1991; 19 : 17-24.

6. Barker SC. Phylogeny and classification, origin and evolution of host association of lice, International Journal for Parasilology. 1994; 24 (8): 1285-1291.

7. Chanlder AC. A study of the structure of feathers with reference to their taxonomic significance, University of California Publications in Zoology. 1916; 13 : 243-446.

8. Clay T. A preliminary survey of the distribution of the Mallophaga (Feather lice) on the class Aves (Birds), J. Bombay Natu. Hist. Soc. 1950; 49 : 430-443, 1950.

9. Clay T. A key to the genera of the Menoponidae (Amblycera: Mallophaga: Insecta), Bull. Brit. Mus. (Natu. Hist.) Entomol. 1969; 24 : 3-26.

10. Clay T. TheAmblycera (Phthiraptera: Insecta), Bull. Brit. Mus. (Natu. Hist.) Entomol. 1970; 25 (3): 75-98, Pls 15.

11. Hopkins GHE, Clay T. A Checklist of the Genera and Species of Mallophaga, Brit. Mus. Natu. Hist. Lond. 1952; 1-362.

12. Howard H. Fossil evidence of avian evolution, Ibis. 1950; 92: 1-21.

13. Howard H. A new wading bird from the Eocene of Patagonia, Am. Mus. Novitates. 1955; 1710 : 1-25.

14. Johnson KP, Whiting MF. Multiple genes and the monophyly of Ischnocera (Insecta: Phthiraptera), Mol. Phylogenetics and Evol. 2002; 22 : 101-110.

15. Johnson KP, Clayton DH. The biology, ecology and evolution of chewing lice, 449-76, In: R. D. Price, R. A. Hellenthal, R. L. Palma, K. P. Johnson and D. H. Clayton, The chewing lice: world checklist and biological overview. Illinois Natural History Survey, Special Publication. 2003; 24 : 1-105 + X.

16. Kim, KC, Emerson KC, Price, RD. Lice, 376-397. In R. J. Flynn [ed.], Parasites of laboratory animals, lowa State University Press, Ames, lowa, U. S. A. 1973.

17. Konigsmann E. Zur Phylogenie der Parametabola unter besonderer Berücks ichtigung der Phthiraptera, Beitr. Entomol. $1960 ; 10$ : 705-744.

18. Lakshminarayana KV. Data book for the study of chewing lice (Phthiraptera: Insecta), Records of the Zoological Survey of India, Miscellaneous publication, occasional papers. 1986; 81 : 1-63.

19. Layal CHC. Phylogeny and classification of the Psocodea, with particular reference to lice (Psocodea: Phthiraptera), Syst. Entomology. 1985; 10 : 145-165.

20. Marshall IK. Congruence and Cospeciation. Morphological and Molecular Phylogenetics of the Amblycera (Phthiraptera) , Ph. D. Thesis, Univ. Glasgow. 2002. 
21. Marshall IK. A morphological phylogeny for four families of amblyceran lice (Phthiraptera: Amblycera: Menoponidae, Boopiidae, Laemobothriidae, Ricinidae), Zoological Journal of the Linnean Society. 2003; 138 : 39-82.

22. Naz S, Rizvi SA, Sychra O. The high rate of infestation of chewing lice (Phthiraptera) in Rock Pigeons (Cloumba livia Gemlin, 1789) in Pakistan, Trpical Zoology. 2010a; 23 : 21-28.

23. Naz S, Rizvi SA. First record of Anaticola crassicornis (Scopoli, 1763) from Goose, from Sindh, Pakistan. Zootaxa. 2010b; 2693: 60 -66.

24. Naz S, Rizvi SA. New species of the genus Chelopistes (Ischnocera: Philopteridae) from Pakistan; Journal of Asia-Pacific Entomology; Korea-Taiwan-Malaysia. 2012; DOI: 10.1016/j.aspen.2011.08.012; 15 (01): 152-160.

25. Richards OW, Davies RG. Mallophaga (biting lice or bird lice), In: Imm's General Textbook of Entomology, (10 ed.) Chapman and Hall, London, 658-669. 1977.

26. Sychra O, Harmat P, Literak I. Chewing Lice (Phthiraptera) on chickens (Gallus gallus) from small backyard flocks in the eastern part of Cech Republic; Vet. Parasitology. 2008; 152 (2008): 344-348.

27. Wappler T, Smith VS, Dalgleish RC. Scratching an ancient itch: An Eocene bird louse fossil; Proceedings of the Royal Society of London. 2004; B (suppl.); Biology Letters; 03bl0387, S2. 